\title{
Heavy Metals and Bacteria; Example of $P$. aeruginosa
}

\author{
Hüseyin Kahraman* \\ Department of Biology, Faculty of Art and Sciences, Inonu University, Turkey
}

*Corresponding author: Hüseyin Kahraman, Department of Biology, Faculty of Art and Sciences, Inonu University, Turkey

\begin{tabular}{|c|c|}
\hline ARTICLE INFO & ABSTRACT \\
\hline Received: 幽 July 28, 2020 & Citation: Hüseyin Kahraman. Heavy Metals and Bacteria; Example of $P$. aeruginosa. \\
\hline Published: 幽 August 10, 2020 & Biomed J Sci \& Tech Res 29(3)-2020. BJSTR. MS.ID.004801. \\
\hline
\end{tabular}

\section{Mini Review}

Heavy metals; they are metals with a density higher than $5 \mathrm{~g} /$ $\mathrm{cm} 3$. Heavy metals, which are the most polluting as terrestrial and aquatic; it can be given as $\mathrm{Cu}^{+2}, \mathrm{Cr}^{+2}, \mathrm{Hg}^{+2}, \mathrm{Cd}^{+2}, \mathrm{Zn}^{+2}, \mathrm{Co}^{+2}$. Metals play a complementary role in living organisms. Some metals (e.g. $\mathrm{Ca}, \mathrm{Co}, \mathrm{Cr}, \mathrm{Cu}, \mathrm{Fe}, \mathrm{K}, \mathrm{Mg}, \mathrm{Mn}, \mathrm{Na}, \mathrm{Ni}$ and $\mathrm{Zn}$ ) are essential and are used in redox processes. They provide molecular balance through electrostatic interactions, act as structural components of various enzymes and take part in balancing osmotic pressure. Some metals, such as $\mathrm{Mn}^{+2}, \mathrm{Cu}^{+2}, \mathrm{Zn}^{+2}, \mathrm{Mo}^{+2}$ and $\mathrm{Ni}^{+2}$, they are essential elements for living organisms. All metals at high concentrations show toxic properties for microorganisms because they damage nucleic acids, disrupt cell membrane functions and suppress enzymatic activities. Toxicity of non-essential metals; It occurs by displacement with essential metals or through ligand interactions. As a result, they can disrupt cell functions and damage the structure of DNA. However, $\mathrm{Cu}^{+2}$ and $\mathrm{Ag}^{+2}$; studies have shown that it blocks many enzyme systems, including respiration [1].

The effect of heavy metals on living things at the community level; overall metabolic activity changes are in the form of diversity and total cell count reduction. Water-soluble free metal ions can penetrate the cell membranes more easily. Microbial metal resistance mechanisms;

a) Precipitation of metals such as phosphates, carbonates and sulfates,

b) Evaporation of metals by adding methyl or ethyl groups,

c) Physical abstinence through exopolymer and membranes through electronegativecompounds, d) Subjected to intracellular separation with energy dependent metal pulse systems and low molecular weight cysteine rich proteins,

e) Membrane can be expressed by causing blockages at the transport system and at the level (level) of the cell wall [2-4].

According to the toxicity studies, in heavy metals; there is a ranking like $\mathrm{Hg}^{+2}>\mathrm{Co}^{+2}>\mathrm{Cd}^{+2}>\mathrm{Cu}^{+2}>\mathrm{Cr}^{+2}>\mathrm{Zn}^{+2}$. This study is accepted by many researchers. Tests carried out in liquid environments are carried out in concentrations of 10-1000 times less than tests carried out in solid environments. The main reason for this is the increased contact surface in the liquid medium [2,4]. Cell surfaces of all microorganisms; it is negatively charged due to the presence of various anionic structures. This feature gives bacteria the ability to bind metallic cations [5]. However, some metal ions at relatively low densities (e.g. $\mathrm{Co}^{+2}, \mathrm{Cu}^{+2}, \mathrm{Zn}^{+2}, \mathrm{Ni}^{+2}$ ); since they are a vital cofactor for metallo-proteins and enzymes, they are also essential for microorganisms [2,4].

Cell wall; it consists of various polysaccharides and proteins. It therefore acts as active sites for their ability to bind metal ions. The oxygen and nitrogen of the amino groups and carboxyl groups of the peptide bonds have coordination bonds with metal ions such as $\mathrm{Pb}^{+2}, \mathrm{Cu}^{+2}$ and $\mathrm{Cr}^{+4}$ [6]. The most important structural region that captures metals in both living and dead cells is polysaccharides. Since intracellular and extracellular accumulations are energyrequiring processes, metal uptake is easier with live cells [7]. Three groups of heavy metals are dealt with; these are toxic metals (such as $\mathrm{Hg}, \mathrm{Cr}, \mathrm{Pb}, \mathrm{Zn}, \mathrm{Cu}, \mathrm{Ni}, \mathrm{Cd}, \mathrm{As}, \mathrm{Co}$ and $\mathrm{Sn}$ ), dispersing metals (such as $\mathrm{Pd}, \mathrm{Pt}, \mathrm{Ag}, \mathrm{Au}$ and $\mathrm{Ru}$ ) and radioactive core metals (U, Th, Ra and 
Am) [8]. Metal absorption by microorganisms; binding, chelation, ion exchange, inorganic precipitation and/or their combination are the most dominant mechanisms. In addition, in the occurrence of all these events; $\mathrm{pH}$ of the solution, heat, interaction with other ions plays an important role [9].

The uptake or absorption of heavy metals by microorganisms is generally classified into three categories;

a) Attachment to the cell surface,

b) Accumulation inside the cell,

c) Accumulation outside the cell.

Since intracellular and extracellular accumulations are energy-requiring processes, metal uptake is easier with live cells [7]. Many studies conducted; has shown that heavy metals can be particularly absorbed on the cell surface, cell walls or by cell envelopes. The outer membrane, together with the peptidoglycan layer of Gram (-) bacteria, forms the cell envelopes of these bacteria and plays an important role in the binding of heavy metals. The most important part of the outer membrane of Gram (-) bacteria is the lipopolysaccharide layer, which provides the formation of chelates with metal ions. The increase in the outer membrane parts, especially the increase of polysaccharides, leads to an increase in heavy metal binding [10]. Generally, all cell surfaces are anionic. However, these surfaces can interact with cationic ions such as metals, and soluble metal ions can be arrested by the cell wall due to attack by negative groups. Peptidoglycan, teicoic acid and teicuronic acid; It contains a large number of electronegative groups such as carboxyl and phosphodiester. For this reason, Gram (+) bacteria generally has a strong interaction feature with cationic metal ions. In contrast, Gram (-) bacteria have a weaker metal binding capacity.

This is because they have a thinner peptidoglycan layer and teicoic acid and teicuronic acid deficiency in the cell wall. However, some studies say the opposite of this [9,11-12]. Mercury-binding (collecting) proteins with sulfhydryl groups containing cysteines have high affinity for metal ions and this is the potential to be used as biosorbents for heavy metals [13]. According to recent studies, bacteria types generally resistant to metal ions belong largely to the Pseudomonas and Proteus genus. The best known among them are; Pseudomonas aeruginosa and Pseudomonas paucimobilis [4]. In addition to heavy metals, Gram (-) bacteria such as Ralstonia metallidurans, Enterobacter cloacae, Thiabacillus ferooxidans and mucilage producing Cyanobacter are also seen [14]. Heavy metal accumulation is significantly influenced by the presence of other metal ions. Cations such as $\mathrm{Mg}^{+2}$ and $\mathrm{Ca}^{+2}$; can often reduce heavy metal inhibition. $\mathrm{Ca}^{+2}, \mathrm{Cd}^{+2}$ and $\mathrm{Zn}^{+2}$ are a strong opponent for attachment. In addition, selective permeability and ion uptake from membranes are regulated by $\mathrm{Ca}^{+2}$. The added $\mathrm{Ca}^{+2}$; functions as a membrane regulator [15].
Gram (-) bacteria, including P. aeruginosa, can be effectively protected against many harmful compounds in the environment due to the presence of a second membrane. The outer membrane has a function like molecular sieve. Among gram (-) bacteria, $P$. aeruginosa is one of the most active secretion species. It has a genome larger than the genome of other Gram (-) bacteria, with approximately 6.3 million base farm size [16]. However, there is a more common resistance mechanism to deal with heavy metal toxicity, such as flow systems. Similar systems are also found in $P$. syringae, E. coli and Staphylococcus aureus. P. aeruginosa; they can produce large amounts of biofilms with exopolysaccharides due to their aerobics, motility, Gram (-) and heteretrof. This polyanionic matrix allows bacteria to adhere to the surface of solids. In the presence of $\mathrm{Fe}$, it causes a strong increase in the bacterial population. This phenomenon may be related to the production of pyoverdin. This molecule increases the dissolution level of iron with its chelation capacities. They have a strong tendency towards heavy metals due to their biofilm formation in general [14].

Biofilm is an extracellular polymeric matrix (EPS), usually consisting of polysaccharides, proteins and nucleic acid. Biofilm contributes to the formation of resistance against antimicrobial agents and heavy metals. EPS contained in a biofilm binds especially polysaccharide components, heavy metals. Logarithmically growing P. aeruginosa is more resistant than stationary phase cells. Biofilm protects bacteria by absorbing heavy metals into EPS [4]. According to studies, P. putida has high $\mathrm{Cu}^{+2}$ binding capacity [11]. P. aeruginosa shows a longer lag phase in the presence of metal ions compared to its absence (mean 6-8 hours). While P. aeruginosa absorbs the highest percentage of $\mathrm{Hg}^{+2}$ in percent, it absorbs at least $\mathrm{Cr}^{+2}$. Absorption percentages of $\mathrm{Cd}^{+2}$ and $\mathrm{Cu}^{+2}$ are almost equal. In the presence of $\mathrm{Cd}^{+2}$, pyocyanine is formed in cultures immediately. $\mathrm{Cu}^{+2}$ and $\mathrm{Cr}^{+2}$ do not have a significant impact on pyocyanin production. However, $\mathrm{Hg}^{+2}$ and $\mathrm{Co}^{+2}$ completely prevent pyocyanin biosynthesis [17]. $\mathrm{Zn}^{+2}$ and $\mathrm{Pb}^{+2}$ ions cause a significant decrease in the bacterial cell density of Pseudomonas sp [18]. P. aeruginosa shows very high resistance especially against $\mathrm{Zn}^{+2}$ and $\mathrm{Cd}^{+2}$. It is also known that the resistance in $P$. aeruginosa is with an active disposal system (eflux system) against these metals [19].

\section{References}

1. Xu Wei hua, Liu Yun guo, Zeng Guang ming, Li Xin, Song Hua xiao, Peng Qing (2009) Characterization of Cr (IV) resistance and reduction by Pseudomonas aeruginosa. Transactions of Nonferrous Metals Society of China 19(5): 1336-1341.

2. A Hassen, N Saidi, M Cherif, A Boudabous (1998) Resistance of environmental bacteria to heavy metals. Bioresource Technology 64(1): 7-15.

3. TM Roane (1999) Lead resistance in two bacterial isolates from heavy metal-contaminated soils. Microbial Ecology 37: 218-224.

4. Gail M Teitzel, Matthew R Parsek (2003) Heavy metal resistance of biofilm and planktonic Pseudomonas aeruginosa. Applied and Environmental Microbiology 69 (4): 2313-2320. 
5. H Hussein, S Farag, K Kandil, H Moawad (2005) Tolerance and uptake of heavy metals by Pseudomonads. Process Biochemistry 40(2): 955-961.

6. Rani Gupta, Prerna Ahuja, Seema Khan, RK Saxena, Harapriya Mohapatra (2000) Microbial biosorbents: Meeting challenges of heavy metal pollution in aqueous solutions. Current Science 78(8): 967-973.

7. Jo Shu Chang, Robin Law, Chung Cheng Chang (1997) Biosorption of lead, copper and cadmium by biomass of Pseudomonas aeruginosa PU21. War Res 31(7): 1651-1658.

8. Jianlong Wang, Can Chen (2009) Biosorbents for heavy metals removal and their future. Biotechnology Advances 27(2): 195-226.

9. P Sar, SK Kazy RK Asthana, SP Singh (1999) Metal adsorption and desorption by lyophilized Pseudomonas aeruginosa. International Biodeterioration \& Biodegradation 44(2-3): 101-110.

10. Nur Koçberber Kılıç, Allan Stensballe, Daniel Erik Otzen, Gönül Dönmez (2010) Proteomic changes in response to chromium (VI) toxicity in Pseudomonas aeruginosa. Bioresource Technology 101(7): 2134-2140.

11. L Wanga, H Chuaa, Q Zhoub, PK Wongc, SN Sina, et al. (2003) Role of cell surface components on $\mathrm{Cu}^{+2}$ adsorption by Pseudomonas putida 5-x isolated from electroplating effluent. Water Research 37(3): 561-568.

12. Hany Hussein, Soha Farag Ibrahim, Kamal Kandeel, Hassan Moawad (2004) Biosorption of heavy metals from waste water using Pseudomonas sp. Electronic Journal of Biotechnology 7(1): 38-46.

ISSN: 2574-1241

DOI: $10.26717 / B J S T R .2020 .29 .004801$

Hüseyin Kahraman. Biomed J Sci \& Tech Res

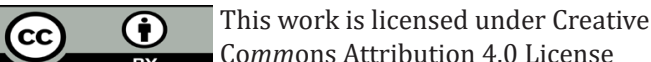

Submission Link: https://biomedres.us/submit-manuscript.php
13. Chieh Chen Huanga, Chi Chia Sub, Ju Liang Hsieh, Chiao Ping Tseng, Ping Jei Lin, et al. (2003) Polypeptides for heavy-metal biosorption: capacity and specificity of two heterogeneous MerP proteins. Enzyme and Microbial Technology 33(4): 379-385.

14. G Aouada, JL Crovisier, VA Geoffroy, JM Meyer, P Stille (2006) Microbiallymediated glass dissolution and sorption of metals by Pseudomonas aeruginosa cells and biofilm. Journal of Hazardous Materials 136(3): 889-895.

15. El Sayed M Soltan, Rehab M Mohamed, Ahmed A Shoreit (2008) Behavioral response of resistant and sensitive Pseudomonas aeruginosa S22 isolated from Sohag Governorate, Egypt to cadmium stres. African Journal of Biotechnology 7(14): 2375-2385.

16. Michael Steinert, Klaus Heuner (2005) Dictyostelium as host model for pathogenesis. Cellular Microbiology 7(3): 307-314.

17. A Hassen, N Saidi, M Cherifh, A Boudabous (1998) Effects of heavy metals on Pseudomonas aeroginosa and Bacillus thuringiensis. Bioresource Technology 65(1-2): 73-82.

18. MO Benka Coker, JA Ekundayo (1998) Effects of heavy metals on growth of species of Micrococcus and Pseudomonas in a crude oil/mineral salts medium. Bioresource Technology 66(3): 241-245.

19. MT Hassan, Daniel van der Lelie, Dirk Springael, U Römling, Nuzhat Ahmed, et al. (1999) Identification of a gene cluster, czr, involved in cadmium and zinc resistance in Pseudomonas aeruginosa. Gene 238(2): 417-425.

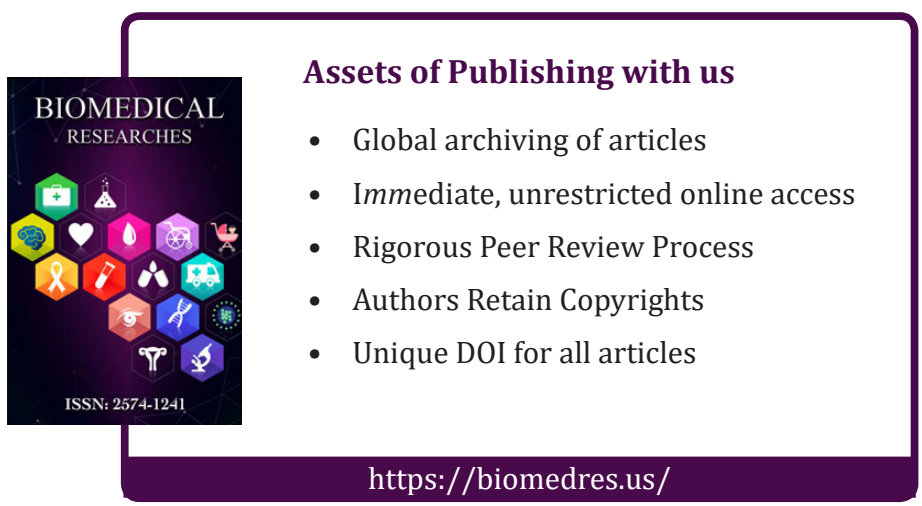

